Kamila Naumowicz (D) https://orcid.org/0000-0002-0953-0708

University of Warmia and Mazury in Olsztyn

\title{
SOME REMARKS TO THE LEGAL STATUS OF PLATFORM WORKERS IN THE LIGHT OF THE LATEST EUROPEAN JURISPRUDENCE
}

\begin{abstract}
The COVID-19 pandemic has had a negative impact on the working conditions of so-called platform workers that have faced the lack of labour and social protection deriving from their formal status of independent contractors. Seeking for protection, numerous claims have been filed by the riders and drivers of digital platforms that were asking for a recognition of the subordinate work. The aim of the present article is to give a critical and brief overview of the latest European jurisprudence regarding the legal status of platform workers. The article focuses on the methodology and criteria applied by the judges in order to examine the particularities of the new forms of work and new forms of surveillance as well. Special attention is paid to on-location work performance by low-skilled individuals conducting services for the digital platforms operating in food delivery and transportation sectors.
\end{abstract}

Słowa kluczowe: platformy cyfrowe, status prawny osób świadczących pracę za pośrednictwem platform, stosunek pracy, samozatrudnienie

Keywords: digital platforms, legal status of the platform workers, employment relationship, self-employment

ASJC: 3308, JEL: K31

\section{Introduction}

In the last years we were observing the constant growth of the so-called gig economy and the creation of the parallel labour market managed by the digital platforms (De Stefano 2016, pp.6-8). As the International Labour Organization stated in its report, we need to bear in mind that "This new form of work has not only disrupted existing business models but also the employment model upon which these business models relied" (Berg et al. 2018, p. V).

It has led to several important questions regarding the legal nature of the platforms and the uncertain legal status of their workers. The working performance organized and 
often controlled by the platforms does not simply enter in the classical dichotomy between subordination and autonomy (Treu 2020), forcing the doctrine and the jurisprudence to examine and reconsider new forms of work and organization of the working process (De Stefano, Aloisi 2018, pp. 41-43) as far as new forms of managerial and control powers, e.g., online reputation and algorithmic scoring systems (Todolí Signes 2021).

The precarious position of platform workers (lack or limited access to social protection including accidents at work and health and safety provisions, lack of protection in case of a termination of the contract) has been highlighted by the COVID-19 pandemic, which placed the platform workers among the most vulnerable groups in the 4.0 labour market. A question of the future of work in the post-pandemic digital labour market has arisen, leading to a concept of decent "digiwork" (Mexi 2020; Świątkowski 2020, p. 228). Noting that, the International Trade Union Confederation has adopted a common statement at the Council of Global Unions asking for the extension of social protection for all workers regardless of their employment status (ITUC 2020).

Recently, the legal status of platform workers, has been examined by several European courts as a consequence of claims filed by riders and drivers of most common digital platforms functioning in the European market. The workers have been asking a recognition of their legal status as employees performing subordinate work. In the proceedings in order to evaluate these claims, the judges have proposed some universal criteria to estimate, whether it is possible to obtain reclassification of the legal status of "independent contractors" into the traditional employment relationship. It has become the question of great importance for the level of protection of the workers as a consequence of this presumption (Garben 2017, p. 89). These criteria are worth a broader analysis as the jurisprudence regarding this matter is addressing one of the basic dilemmas that we are facing in the gig economy-are we dealing with new or old forms of work (Todolí Signes 2017; Unterschütz 2020b, pp. 319-323) and if such, how to guarantee the basic rights of the worker and to what extend this protection should and might include the platform workers defined as "independent contractors" (Świątkowski 2019, pp. 149-166).

This discussion may be an important contribution for the Polish legislator that till now has not addressed the question of the legal status of the platforms and platform workers (Haipeter et al. 2020, p. 15; Naumowicz 2020b).The controversies arising in different European states may though contribute to the general movement among the platform workers seeking decent working conditions and protection from the state and its legal system (Naumowicz 2020a).

\section{The diversity of digital platforms and their organization}

In order to analyse the relationships between platform workers and the platform, a question that demands a previous response is the legal nature of the platform itself. One needs to take into consideration that digital platforms in spite of several similarities among 
them do not represent a homogeneous category. Furthermore, it might be observed that they are realizing a new business model representinga different organizational structure (Acquier 2018, p. 15).

For the further analysis of the European jurisprudence, it is crucial to understand the division of the platforms as proposed by the Eurofound. They are classified based on such criteria as the on-location or web-located working performance and as a second criteria-a level of skills necessary to perform tasks by the platform workers: low, medium or high (Eurofound 2019, pp. 5-6; Unterschütz 2020a, p. 7).

The European courts in the commented rulings have examined questions regarding the legal status of the workers mainly of the on-location platforms operating in the sectors of food delivery and transportation. The workers were low-skilled workers, drivers or riders (defined by the platforms as self-employed independent contractors) who performed work in person and on-location, conducting tasks assigned by the platform. These platforms may intervene in different ways in their working performance througha digital scoring and managing system. In fact, as noticed by the doctrine, platforms are often pretending to be a mere intermediary between contractors (workers and the clients). Thus, the classical dichotomy between autonomy and subordination cannot be easily applied to these new organizational models of management, where the control of the workers is exercised rather through algorithms and rating systems than through typical subordination (Chesalina 2020, p. 154).

\section{The legal status of platform workers in the latest European jurisprudence}

One of the latest rulings in terms of platform work has been delivered by the Tribunal of Palermo on the 20 November 2020 (judgment of the Tribunal of Palermo of 20 November 2020, No. 3570/2020, hereinafter referred to as: Palermo No. 3570/2020). ${ }^{1}$ The judgment might be seen as a consequence of several previous rulings of Italian and European courts that together have determined some universal criteria for the evaluation of the legal status of platform workers.

In the commented case, a rider of the platform "Glovo" filed an appeal to the Tribunal of Palermo, asking for a recognition of the employment relationship as subordinate and the application of the discipline of subordinate work to his working activity, including the discriminatory dismissal that the company had conducted. The appellant has carried out his activity as a rider continuously since 28 September 2018 until 3 March 2020, when he was disconnected from the platform and unable to reconnect again. Despite repeated requests to regain connection to the platform, the rider has not received a proper explanation of the deactivation of his account, that deprived him of the

$1 \mathrm{http} / /$ www.rivistalabor.it/wp-content/uploads/2020/12/Trib.-Palermo-24-novembre-2020-n.-3570. pdf (access: 15 February 2021). 
possibility to perform any service. Furthermore, the rider claimed that his dismissal was a discriminatory action of the company, as a reaction to his numerous requests made shortly before the disconnection regarding the application of more transparent and favourable working conditions by the company and the lack of individual protection supplies for the riders. The rider described in details his working conditions, stating that the company exercised managerial and control power toward him, including scoring system and sanctions (e.g., repeatedly blocking his account that deprived him from the possibility to perform work).

\section{The legal nature of digital platforms}

To resolve the problem of the legal qualification of the employment status of "riders," the Tribunal of Palermo, firstly addressed the general question of the characteristics and legal nature of digital platforms. As the Tribunal stated:

Preliminarily, therefore, the objective of these platforms must be analysed and identified, and in particular whether (the objective) is to put users in contact, carrying out a mere intermediation activity, or if it is a business activity of transport of people or home delivery of food and beverages (Palermo No. 3570/2020).

In the analyzed case, the digital platform was a part of the activity of a Spanish multinational company Foodinhos.r.l. functioning under the brand "Glovo" that operates in the delivery sector in Italy since 2016. As it has been stated by the company itself its main activity was the management of an online software platform and mobile applications for smartphones that connect users (consumers), local businesses (mostly restaurants) and home delivery providers to allow consumers to purchase meals/goods through the platform and receive them delivered at home.

Contrary to these statements, however, the Tribunal of Palermo based its recognition of the legal nature of the platform on the international jurisprudence regarding digital platforms. First of all, one of the main rulings in the matter that had to be mentioned, was that of the Court of Justice of the European Union (CJEU), in which the legal status of the platform was recognized as a business activity with the main purpose of transporting people or home delivery of food and beverages (judgment of the CJEU of 20 December 2017, C-434/15).

In the cited judgmentof the CJEU, the request for a preliminary ruling has been made by the Commercial Court of Barcelona in the proceeding between Elite Taxi, a professional taxi drivers' association in Barcelona (Spain), and Uber Systems Spain SL, a company related to Uber Technologies Inc. Elite Taxi accused Uber Systems Spain of unfair competition and misleading practices, infringing the Spanish competition law.In order to resolve the question, the Court firstly needed to determinethe legal classification of the services provided by the platform-as information society service 
(intermediary electronic service connecting the owner of a vehicle and a person who needs to make a journey within a city), or a transport service.

In that regard, the CJEU examined the specific circumstances in which the intermediation service was provided by Uber. The service was based on the selection of non-professional drivers that were using their own vehicles to perform work. Though, the Court took into consideration the fact, that the company provides to these drivers an application without which they would not be able to provide the transport services. Also the potential clients of the drivers would not use their services without the application. Furthermore, the Court has also considered the influence of the Uber on the conditions of the service, which include, e.g., determining the maximum fare of the service through the application, receiving the payment from the client before paying the driver for the service and exercising a control power over the drivers, their service and the quality of the vehicles they use. Taking these circumstances into account, the CJEU stated that:

That intermediation service must thus be regarded as forming an integral part of an overall service whose main component is a transport service and, accordingly, must be classified not as "an information society service" within the meaning of Article 1(2) of Directive 98/34, to which Article 2(a) of Directive 2000/31 refers, but as "a service in the field of transport" within the meaning of Article 2(2)(d) of Directive 2006/123 (judgment of the CJEU of 20 December 2017, C-434/15 \$\$ 39, 40).

\section{The influence of the legal nature of the platform on platform workers}

According to the Tribunal of Palermo, the identification of the legal nature of digital platforms as business activities carrying out transport or delivery services, has a crucial effect on the qualification of the employment relationship. It needs to be underlined, that in case the platform can be considered as a company, there is a possibility to consider its collaborators as working on behalf of the platform and included in its entrepreneurial organization. On the other hand, if we consider the activity of the platforms only as a mere intermediary activity between users and those who perform the service, the nature of the contract may be seen in a different perspective. These interpretative difficulties have been underlined also by the doctrine in the last years:

The underlying contract might be classified a contract of employment or a contract for services, depending on the applicable tests in each jurisdiction-from the intensity of the influence the contractual partner has on the work performed to economic dependency and permanence of the contractual arrangement (Adams-Prassl, Risak 2016, p. 13).

On this basis, considering the purpose and the nature of the service provided, the Tribunal stated that the platform Glovo should be recognized as a business activity 
of food delivery. This presumption, though, opens the question of the legal nature of the relationship between the riders (or drivers in case of transport of persons) and the platform. With the reference to numerous previousrulings, it has to be acknowledged that the matter in question was mainly the classical division between subordination and autonomy (judgment of Tribunal of Milano (Tribunale di Milano) of 25 May 2015, No. 16612/2015; judgment of Tribunal of Torino (Tribunale di Torino) of 1 March 2017, No. 1553/2017) and for that reason the general principles regarding subordination and autonomy in the employment relationship had to be reaffirmed by the court. In fact, in the cited jurisprudence the courts haveeither expressly ruledthat the subordination exists in the relations between the riders and the delivery companies, or that their relationship is characterized by the autonomy of the parties.

To ascertain in the specific case which regime to apply to the rider, the Tribunal referred to the criteria indicated in the CJEU ruling of 22 April 2020 (order of the CJEU of 22 April 2020, C-692/19 $\$ \$ 27-32$ ). In the cited judgment, the preliminary question considered the methods to evaluate whether a person (a rider or a driver) engaged by the platform under an agreement stipulating he/she is a self-employed independent contractor, can be classified as a "worker" (in the case above the question considered the meaning of the "worker" in terms of the Directive 2003/88). To answer this question the Court stated that, first of all, it should be noted that the Directive does not define the concept of "worker," though the CJEU has ruled on its specific autonomous meaning in the EU law in different rulings (judgment of the CJEU of 20 November 2018, C-147/17 $\$ 41$; judgments of the CJEU of 14 October 2010, C-428/09 \$29; judgment of the CJEU of 26 March 2015, C-316/13\$29).

According to the CJEU, it is up to the national court to determine, whether the concept of a "worker" is applicable in the examined case, based on objective criteria and evaluation of all the circumstances of the relationship of the parties involved. In order to determine whether a person carries out the activity under the direction of another, the judge needs to evaluate the existence of a hierarchical relationship between the worker and his employer (judgment of the CJEU of 10 September 2015, C-47/14 $\$ 46$; judgment of the CJEU of 20 November $2018, C-147 / 17 \$ 42)$ and the direction of another person in the working performance (judgment of the CJEU of 26 March 2015, C-316/13 \$27; judgment of the CJEU of 21 February 2018, C-518/15\$28) taking into consideration all the objective circumstances of the relationship between the parties. Thus, while examining whether a person can be classified as "independent contractor," his/her independence cannot result merely notional and disguising an employment relationship (judgment of the CJEU of 4 December 2014, C-413/13 \$35).

\section{The managerial and control power executed by the platforms}

In the light of the CJEU jurisprudence, the criteria typically associated with the independent contractors include the choice of the type of work and tasks to be executed, 
the manner in which that work or those tasks are to be performed, the time and place of work, and the freedom in the recruitment of subcontractors (judgment of the CJEU of 10 September 2014, C-270/13 \$33). From the examination of these criteria, it may result though that the person hired as independent service provider under the national law, in fact performs the activity under the direction of others and his/her freedom to choose the time, place and content of the work are limited (judgment of the CJEU of 4 December 2014, C-413/13 \$36). For example, as in the analysed case, if the agreement between the parties allows the person:

- to use subcontractors or substitutes to perform the service which he has undertaken to provide;

-to accept or not accept the various tasks offered by his putative employer, or unilaterally set the maximum number of those tasks;

- to provide his services to any third party, including direct competitors of the putative employer, and - to fix his own hours of "work" within certain parameters and to tailor his time to suit his personal convenience rather than solely the interests of the putative employer,

it must be interpreted as precluding a person from being classified as a "worker" but only if:

the independence of that person does not appear to be fictitious and, second, it is not possible to establish the existence of a relationship of subordination between that person and his putative employer (order of the CJEU of 22 April 2020, C-692/19 \$45).

The methods of carrying out the working performance, need to be carefully analysed by the judge in every case, in order to evaluate the legal nature of the relationship of the parties.From the actual circumstances examined by the Tribunal of Palermo, it emerged that the rider performed his activity for the delivery company for about 8 hours per day and his activity was organized and managed fully by the digital platform, through which access he could only render the service. Furthermore, it has been proved that the assignment of the delivery took place on the basis of an algorithm that evaluated the location of the rider with respect to the restaurant and/or the place of delivery. The platform managed the working performance through a scoring system based on various parameters. Each rider has been assigned a score depending from his/her efficiency, users or partners feedbacks and the worker's experience. The booking of time slots in which the delivery service would be assigned to a certain worker depends on the score of the worker. Therefore, the higher the score the more possibility the rider had to book better time shifts.

The control of the platform regarded also several conditions of the working performance, e.g., in order to perform work the rider was obliged to have the mobile phone with the battery charge not less than $20 \%$ for all the time he was being logged-in to the platform. In case he did not fulfil this criteria, the algorithm would not select him for the delivery. 
The platform also exercised its managerial power through a sanctioning system-the algorithm would reduce the score of the worker based on the conduct of workif, e.g., the driver refused to provide a service in a previously declared shift. According to the Tribunal of Palermo, it has to be considered as the exercise of disciplinary power by the company and therefore an indication of managerial an control power existing within an employment relationship.

The evaluation of the circumstances indicated above, have led to the recognition of the rider's subordination to the managerial, control and disciplinary power of the employer. The freedom of the rider to choose if and when to work was only notional, as it was limited by the platform's algorithms, including the scoring system and sanctioning (Fava 2021, p. 5).

The Tribunal of Palermo has agreed upon the legal status of Glovo riders with the previous ruling of the Supreme Court of Spain (judgment of the Supreme Court of Spain (Tribunal Supremo) of 25 September 2020, No. 805/2020). ${ }^{2}$ In this case, the sentence of the Supreme Court was a result of the claim filed by a rider against Glovo, asking to be reclassified as an employee. The Spanish courts of the first and the second instance declared he was an autonomous contractor, which has only been revoked by the Supreme Court confirming his subordinate working status (Todolí Signes 2020, pp. 4-5). What has been considered by the Supreme Court and deserves a further recognition is the fact that, as the Court stated: "Since the creation of labour law up to the present time we have witnessed an evolution of the dependency-subordination requirements."

Thus, while examining the legal status of the riders, we have to take into account the modern concept of dependency in the post-industrial society that owing to the use of technological innovations have become more flexible and takes a form of digitalized control systems. As the Supreme Court noticed: "The existence of a new productive reality forces us to adapt the notes of dependency and alienation to the social reality of the time in which the rules must be applied." The Supreme Court agreed that the scoring system managed by the algorithms of the platform and the establishment of the digital reputation of the rider is a tool used by the company for the surveillance and control of the workers, as well as a form of the organization of their work.

In its sentence the Supreme Court took into consideration also the following methods of the organization of work used by Glovo towards its riders, leading toward the recognition of the subordinate work relationship: deciding upon the price of the service, the payment methods and remuneration of the riders that received they payment not directly from the clients but subsequently from the platform itself; not being involved in any business decisions made by the company, nor in the agreements between Glovo and the clients (business activities whose products were distributed by the riders); impossibility to conduct the delivery service without the use and connection to the platform and the application managed by Glovo (Todolí Signes 2020, pp. 10-11).

2 https://www.poderjudicial.es/search/AN/openDocument/05986cd385feff03/20201001 (access: 15 February 2020). 
In fact, in the Italian case resolved by the Tribunal of Palermo, the same circumstances of the working performance, have led the Italian court to the recognition of subordinate work of the rider, stating after the Supreme Court of Spain that:

if it is concluded that the plaintiff's independence was merely apparent and there was in fact a subordination of the applicant [with respect to] Glovo, cited ruling of the ECJ [C-692/19] will not prevent the qualification of the employment relationship for these purposes (Palermo No. 3570/2020).

The rider of Glovo resulted to be fully dependent in his working performance from the possibility to connect to the platform. In fact, when the company has blocked his connection to the application (without a proper justification), he was unable to perform any service. As the Tribunal explained:

beyond the apparent and declared (in the contract) freedom of the rider, and of the applicant in particular, to choose the working times and whether or not to perform work, the organization of work operated exclusively by the respondent party on the digital platform (Palermo No. 3570/2020).

that with the assumption of:

the employee making their working energies available to the employer for substantial periods of time (which is unpaid) [and] the exercise by the defendant of powers of direction and control (Palermo No. 3570/2020),

constitute the elements of the subordinate work according to the Art. 2094 of the Italian Civil Code. To justify its ruling, the Tribunal cited also one of the latest sentences of the Court of Cassation (on the Foodora case: judgment of the Court of Cassation (Corte di Cassazione) of 24 January 2020, No. 1663/2020 $\$ 42$ ), ${ }^{3}$ which remarked-as mentioned above-that the recognition of the subordinate work is decisively influenced by the actual circumstances of the working performance, by the results of the court's examination of these circumstances and the judge's assumption whether the investigation carried out by the court is sufficient to find the symptomatic elements of the subordination such as to consider it to be proven.

In the light of the commented jurisprudence, it is important to mention another significant ruling given by the Supreme Court of the United Kingdom (judgment of the Supreme Court of the United Kingdom of 19 February 2021, UKSC 2019/0029, on appeal from: EWCA Civ 2748 [2018]). ${ }^{4}$ The ruling has ended a long legal battle started

3 http://www.bollettinoadapt.it/wp-content/uploads/2020/03/Cassazione-1663-2020-riders.pdf (access: 15 February 2021).

${ }^{4}$ https://www.supremecourt.uk/cases/uksc-2019-0029.html (access: 23 February 2021). 
in 2016 against Uber $^{5}$ by its previous drivers, asking to be recognized as workers and not self-employed (as the platform claimed). The Court has unanimously dismissed the appeal of the company, sustaining the previous rulings of the Court of Appeal and the Employment Tribunal.

In this case the Supreme Court examined two important questions that have arisen during the proceedings, regarding the legal status of the drivers. First of all, a response had to be given to the general question, whether the Employment Tribunal was entitled to recognize the legal status of the drivers performing their work through the Uber's smartphone application (defined as "the Uber app") as workers and not independent contractors as Uber claimed. According to the appellant, the drivers were self-employed and providing services under contracts stipulated directly with their clients by the use of the Uber's platform (as the booking agent and intermediary party). If, though, the respondents were to be classified as workers, the second question was: what periods constituted their "working time"-only when driving a passenger (as Uber argued) or whenever they werelogged in to the Uber's application and ready to accept the task. Considering the circumstances of the working performance of the drivers, the Court decided that the drivers were in a position of subordination to Uber.

The Court took into consideration the following factors: "the relative degree of control exercised by Uber and drivers respectively over the service provided [to the passengers]" and in particular "who determines the price charged to the passenger ... who is responsible for defining and delivering the service provided to passengers." A final remark has been related to "the extent to which the arrangements with passengers afford drivers the potential to market their own services and develop their own independent business" (judgment of the Supreme Court of the United Kingdom of 19 February 2021, UKSC 2019/0029 \$92). The circumstances of the working provisions justified the conclusion that the drivers were performing work for and under contracts with Uber and not with the passengers. One of the factors of the mayor importance for the Court was the fact that the drivers had no autonomy in fixing the price for the service as it was dictated by the Uber app. Uber also gains control over the drivers' remuneration, by fixing the "service fee" deducted from the fares paid to drivers after the service and having the sole discretion in deciding on the possible refund to a passenger in response to his/her complaint about the trip.

Furthermore, Uber has also dictated the contractual terms of the service provision to the drivers, imposing on them detailed standards of service performance which drivers are expected to meet. In case they fail to meet the standards, different actions are taken by the company, regarding a system of monitoring and penalization of the drivers. As the Court stated: "Taking these factors together, it can be seen that the transportation service performed by drivers and offered to passengers through the Uber app is very

5 The appellants were precisely: Uber BV—a Dutch company which owns the rights in the Uber app; and two subsidiaries of the Uber BV in the United Kingdom: Uber London Ltd and Uber Britannia Ltd, that have been licensed to operate private hire vehicles in London and outside. 
tightly defined and controlled by Uber" (judgment of the Supreme Court of the United Kingdom of 19 February 2021, UKSC 2019/0029 \$101), which justified the Court's final decision as whether the claimants are to be regarded as working under contracts with Uber (as the Court ruled) and not to be regarded as performing services solely for and under contracts made with passengers through Uber as a booking agent (as Uber claimed).

\section{Conclusions}

As results from the analysis of the cited jurisprudence, digital platforms (Glovo and Uber) have not been recognized as merely intermediation services, buttransportation and/or delivery business activities. This affirmation has deep consequences for the legal status of the riders/drivers that perform their services through and "for" the platform.

It led the courts to the conclusion that offering to the riders/drivers working conditions that guarantee to them only mere and apparent autonomy in the contract but an actual dependence from the company, does not preclude a recognition of subordinate work relationship between the worker and the platform (Todolí Signes 2020, p. 12).

What needs to be underlined is the methodology used by the courts to examine the actual working conditions, that on the one hand precluded the traditional classification of subordination and autonomy, but on the other hand resulted in the juridical evaluation of new forms of dependence and control that appeared in the gig economy and the digital era of work.

Though, one still has to take into account, that despite some similarities and common features in the working performance of platform workers, in each case we may encounter important differences and "looking at labour platforms as a unified whole could be inappropriate as well as misleading" (De Stefano, Aloisi 2018, p. 14). In the cases presented above the matter considered the legal status of riders and drivers working for digital platforms operating in transportation and food delivery services. But similar legal uncertainties should be examined for a different type of digital platforms that are web-based, online platforms operating in a multinational environment and like most of the platforms-classifying their workers as self-employed autonomous contractors, which to the same extendleads to lack of labour and social protection (ILO 2019, pp. 3-4). These questions also deserve a further discussion.

\section{References}

Acquier A. (2018) Uberization Meets Organizational Theory. Platform Capitalism and the Rebirth of the Putting-Out System [in:] N. Davidson, M. Finck, J. Infranca (eds.), Cambridge Handbook of the Law of the Sharing Economy, Cambridge.

Adams-Prassl J., Risak M. (2016) Uber, Taskrabbit, \& Co: Platforms as Employers? Rethinking the Legal Analysis of Crowdwork, "Comparative Labor Law \& Policy Journal," Vol. 37, Issue 3. 
Berg J., Furrer M., Harmon E., Rani U., Six Silberman M. (2018) Digital Labour Platforms and the Future of Work. Towards Decent Work in the Online World, Geneva, https://www. ilo.org/wcmsp5/groups/public/---dgreports/---dcomm/---publ/documents/publication/ wcms_645337.pdf (access: 15 February 2021).

Chesalina O. (2020) Platform Work as a New Formof Employment: Implications for Labour and Social Law [in:] J. Wratny, A. Ludera-Ruszel (eds.), New Forms of Employment. Current Problems and Future Challenges, Wiesbaden.

De Stefano V. (2016) The Rise of "Just-in-Time Workforce": On Demand Work, Crowdworkand Labour Protection in "Gig Economy", Geneva.

De Stefano V., Aloisi A. (2018) European Legal Framework For "Digital Labour Platforms", Luxembourg, https://publications.jrc.ec.europa.eu/repository/bitstream/JRC112243/ jrc112243_legal_framework_digital_labour_platforms_final.pdf (access: 15 February 2021).

Haipeter T., Owczarek D., Faioli M., Iudicone F. (eds.) (2020) Don't Gig up! Project. Final report, https://www.isp.org.pl/pl/publikacje/dont-gig-up-final-report (access: 15 February 2021).

Eurofound (2019) Platform Work: Maximising the Potential While Safeguarding Standards?, Luxembourg.

Fava G. (2021) Nota allasentenza del Tribunale di Palermo n. 3570/2020 pubbl. il 24/11/2020. Il rapporto di lavoro dei riders, "Lavoro Diritti Europa," n. 1, https://www.lavorodirittieuropa.it/ images/Nota_a_sentenza_Tribunale_di_Palermo_Rider_fava.pdf (access: 15 February 2021).

Garben S. (2017) Protecting Workers in the Online Platform Economy: An Overview of Regulatory and Policy Developments in the EU, European Agency for Safety and Health at Work, Luxembourg.

ILO (2019) Policy Responses to New Forms of Work: International Governance of Digital Labour Platforms, https:/www.ilo.org/wcmsp5/groups/public/---dgreports/---cabinet/documents/ publication/wcms_713378.pdf (access: 15 February 2021).

ITUC (2020) COVID-19: Urgent Economic Stimulus and Workplace Measures Required, https:// www.ituc-csi.org/covid-19-urgent-economic-stimulus?lang=en (access: 15 February 2021).

Mexi M. (2020) The Future of Work in the Post-Covid-19 Digital Era, https://www.socialeurope. eu/the-future-of-work-in-the-post-covid-19-digital-era?fbclid=IwAR3Y6b_Jxr83WB4ZnY--3NqBGEHXJXwsUTKK41KAf4NujZHXuwNxpQLVZEY (access: 15 February 2021).

Naumowicz K. (2020a) Digital Nomads on Polish LabourMarket: Legal Situation, Risks and Expectations [in:] A. Perulli, T. Treu (eds.), The Future of Work: Labour Law and Labour Market Regulation in the Digital Era, Alphen aan den Rijn.

Naumowicz K. (2020b) Report on the State of Polish Legislation of Modern Forms of Work [in:] S. Bellomo, F. Ferraro (eds.), Modern Forms of Work: a European Comparative Study, Roma. Świątkowski A.M. (2019) Elektroniczne technologie zatrudnienia ery postindustrialnej, Kraków. Świątkowski A.M. (2020) The Phenomenon of Digital Labour Platforms, "Studia z Zakresu Prawa Pracy i Polityki Społecznej," t. 27, nr 4.

Todolí Signes A. (2017) The End of the Subordinate Worker? The On-Demand Economy, the Gig Economy, and the Need for Protection for Crowdworkers, "International Journal of Comparative Labour Law and Industrial Relations," No. 2. 
Todolí Signes A. (2020) Comentario a la Sentencia del Tribunal Supremo español que considera a los Riders empleadoslaborales: Tribunal Supremo Sala de lo Social, 25 de septiembre de 2020, No 805, “Labour \& Law Issues," Vol. 6, No. 2.

Todolí Signes A. (2021) The Evaluation of Workers by Customers as a Method of Control and Monitoring in the Firm: Digital Reputation and Data Protection, "International Labour Review," Vol. 160, No. 1.

Treu T. (2020) The ILO and the Future of Work [in:] A. Perulli, T. Treu (eds.), The Future of Work: Labour Law and Labour Market Regulation in the Digital Era, Alphen aan den Rijn.

Unterschütz J. (2020a) Collective Bargaining for Platform Workers: a Hope for new Developments?, "Hungarian Labour Law E-Journal," No. 2.

Unterschütz J. (2020b) Digital Labour Platforms: Dusk or Dawn of Labour Law? [in:] J. Wratny, A. Ludera-Ruszel (eds.), New Forms of Employment. Current Problems and Future Challenges, Wiesbaden.

\section{Court sentences}

Judgment of the Court of Cassation (Corte di Cassazione) of 24 January 2020, No. 1663/2020. Judgments of the CJEU of 14 October 2010, C-428/09, Union syndicaleSolidaires Isère v. Premier ministre and Others, ECLI:EU:C:2010:612.

Judgment of the CJEU of 10 September 2014, C-270/13, IraklisHaralambidis v. CalogeroCasilli, ECLI:EU:C:2014:2185.

Judgment of the CJEU of 4 December 2014, C-413/13, FNV KunstenInformatieen Media v. Staat der Nederlanden, ECLI:EU:C:2014:2411.

Judgment of the CJEU of 26 March 2015, C-316/13, Gérard Fenoll v. Centre d'aide par le travail "La Jouvene," Association de parents et d'amis de personneshandicapéesmentales (APEI) d'Avignon, ECLI:EU:C:2015:200.

Judgment of the CJEU of 10 September 2015, C-47/14, HoltermanFerhoExploitatie and Others v. Friedrich Leopold Freiherr Spies von Büllesheim, ECLI:EU:C:2015:574.

Judgment of the CJEU of 20 December 2017, C-434/15, AsociaciónProfesionalÉliteTaxi v. Uber Systems Spain SL, ECLI:EU:C:2017:981.

Judgment of the CJEU of 21 February 2018, C-518/15, Ville de Nivelles v. Rudy Matzak, ECLI:EU:C:2018:82.

Judgment of the CJEU of 20 November 2018, C-147/17, Sindicatul Familia Constanţa, Ustinia Cvas and Others v. Direcția Generală de Asistență Socialăși Protecția Copilului Constanța, ECLI:EU:C:2018:926.

Judgment of the CJEU of 22 April 2020, C-692/19, B v. Yodel Delivery Network Ltd, ECLI:EU:C:2020:288.

Judgment of the Supreme Court of Spain (Tribunal Supremo) of 25 September 2020, No. 805/2020. Judgment of the Supreme Court of the United Kingdom of 19 February 2021, UKSC 2019/0029. Judgment of Tribunal of Milano (Tribunale di Milano) of 25 May 2015, No. 16612/2015. Judgment of the Tribunal of Palermo of 20 November 2020, No.3570/2020.

Judgment of Tribunal of Torino (Tribunale di Torino) of 1 March 2017, No. 1553/2017. 